Kudyrko Liudmyla, $\mathrm{PhD}$ in Economics, Prof., Kyiv National University of Trade and Economics (Ukraine) ORCID 0000-0002-9089-7223,

Researcher ID L-7571-2016 Samsonova Liliia, $\mathrm{PhD}$ in Economics, Kyiv National University of Trade and Economics (Ukraine) ORCID 0000-0002-7285-9549

ResearcherID N-6610-2016

\title{
DETERMINANTS AND PROSPECTS FOR THE DEVELOPMENT OF INTERNATIONAL CONTRACT RELATIONS IN UKRAINE
}

Determination that contractual relations in the format of international production and marketing cooperation should be considered as the component of combined model for national economic development, which is to combine both external and internal sources and reserves of expanded reproduction through the activization context of nonprotectionist tendencies in the leading countries of the world and intensification of risks withinnational development. The sectoral specificity of contractual relations development in Ukraine has been analyzed, which testifies low diversification in the global tendencies and the priority of limited range of agreements, namely contract manufacturing. Determinants are found to impede the further development of contractual relationships such as weak institutional support, lack of legislative basis, and adequate logistical and organizational infrastructure. It is substantiated that serious complication in predicting the volume and structure of operations mediated by international contractual relations is the imperfection indicator of the national accounting system and the low motivationfactorfor business, integrated into international cooperative activities up to promulgationof operations under study. The perspective types of international contractual relations with the participation of domestic business as manufacturingas well as contract management, outsourcing and licensing have been defined during research.

Key words: contract relations, international cooperation, contract production, licensing, franchising.

Кудирко Людмила, Самсонова Лілія. Детермінанти та перспективи розвитку міжнародних контрактних відносин в Украӥні.

Визначено, щуо контрактні відносини в форматі міжнародної виробничої та збутової кооперачії варто розглядати в якості складовоїкомбінованої моделі 
національного економічного розвитку, яка поєднуватиме як зовнішні, так і внутрішні джерела та ресурси розширеного відтворення в умовах активізації непротекціоністських тенденцій в провідних країнах світу та посилення ризиків внутрішньонаціонального розвитку. Проаналізовано секторальну специфіку розвитку контрактних відносин в Україні, щуо засвідчило їх слабку диверсифікованість щзодо загальносвітових тенденцій та пріоритетність обмеженого кола угод, а саме виробництво за контрактом. Виявлено детермінанти, щуо стримують подальший розвиток контрактних відносин, а саме слабке інститучійне забезпечення, брак законодавчої підтримки та належної матеріальнотехнічної та організаційної інфраструктури. Обгрунтовано, щзосерйозним ускладненням для прогнозування обсягів та структури операщій, щуо опосередковуються міжнародними контрактними відносинами, є недосконалість національної системи обліку та низька мотиващія бізнесу, щзо інтегрований в міжнародну коопераџійну діяльність, до оприлюднення окреслених операцій. Визначеноперспективні види міжнародних контрактних відносин за участі вітчизняного бізнесу в якості виробництва та управління за контрактом, аутсорсингу, лічензування.

Ключові слова: контрактні відносини, міжнародна кооперація, виробництво за контрактом, ліцензування, франчайзинг.

Relevance of the research topic. The geospatial transformation of Ukraine's external sector is taking place under conditions of serious internal and external challenges. In particular, it is the threat of further escalation of hostilities in the east of the country, maintaining high level of foreign trade openness and dependence on the global commodity markets, loss of human resources from the point of view of largescale migration out from the country andinhibition of investment activity [6].

In addition, the existing high level of basic industries fundswearing-outmakes it difficult to solve the issue of improving competitiveness of manufactured products. The decades-old formed structure of export-oriented production of low-tech products increases the risk for the national economy to remain for economically developed countries only an «ancillary» economy with high levels of labor and energy intensity, butat the same time with low labor efficiency, and an overwhelming share of intermediate consumption that has no external demand being entirely depended on price fluctuations on the world markets [5].

Taking into account the current status of national and world economies, Ukraine cannot rely on the priority of developing only export potential and the orientation of domestic production (mainly tolling raw materials and primary processing) onto the foreign market. After all, in the context of intensifying nonprotectionist tendencies in the leading countries of the world and in order to achieve stable social and economic development of modern Ukraine, it is necessary to implement a combined model of economic growth, which is to combine both external 
and internal sources and resources of expanded reproduction. In our opinion, one of the possible components within the outlined model could be the use of non-joint-stock forms of international production (contractual relations, hereinafter referred to as CR) with the participation of domestic enterprises [7].

Formulation of the problem. The scientific and practical problem of assessment for the prospects and effects of national enterprises participation in the system of international cooperative relations through the mechanism of noninvestment contractual agreements is currently being updated. Such an understanding makes it possible to evaluate more critically the directions of adjusting the institutional impact on the localization of production processes and technological stages on the territory of definite countries.

Analysis of recent researches and publications. The generalized results of empirical studies dedicated to the assessment of the macroeconomic effects created by countries inclusion in the global value chains through contractual relation are presented in the works of S. Miroudot, R. Lanz and A. Ragoussis [4] Sectoral peculiarities of the international business development through modern contractual forms are disclosed in the works of Reznikova N. [8], ZvarychI.[16], DuhinetsG. [1], Mazaraki A., Melnichenko S. [2], Melnyk T. \& Kudyrko L. [3], Rohach O. [9].

Setting objectives. The complications in determining the prospects for the development of international contractual relations with the participation of Ukrainian enterprises have led to the necessity ofdefining the directions for further integration of domestic business into the system of global production and marketing cooperation. This approach made it possible to identify projected volumes of export and import of transactions mediated by contractual relations and, on this basis, to determine the necessary conditions for their further development in Ukraine.

Presenting main material. For Ukraine the difficulty of contractual relations formation through means of international production or marketing cooperation is not only because they are relatively new phenomenon on the national territory. Obviously, Ukrainian companies have a weaker resource and organizational position as for nonresident companies.

Complications for the development of international cooperative relations are also exist due to the fact that Ukraine is being in lack of basic legal framework that could resolve all contentious and risky issues of contractual relations. Generally unstable political and economic situation in the country is also being added, which affects the efficiency of all business areas, not just activities resting on international contractual relations. In addition, there are objective obstacles to the implementation of CR, including: poorly developed logistics network and transport infrastructure; long and costly customs clearance procedure; the price forspare components (parts) in Ukraine, which is sometimes higher than in the country of origin; poor quality control of production; long-term and relatively expensive certification of products; comparatively small number of contractors who can provide «complete» services; high cost for services in the case of low-volume orders. 
On the other hand, foreign customers of contract relations are attracted by Ukraine's undeniable advantages: first, the availability of free production facilities, the level of automation of which is much higher than the underdeveloped African and Asian countries; second, skilled workers supply; third, the low cost of quality labor in comparison with the cost of labor in the contracting countries; fourth, the geographical closenessto the CIS and European markets and the similarity of the consumption model [15].

The most widespread type of $\mathrm{CR}$ that has found application in building cooperative partnerships among Ukrainian enterprises is the contract manufacturing, namely, in the field of processing raw materials. Complication for assessments of the scale of cooperation between Ukrainian enterprises and foreign partners in the context of other types of contractual relations is that there is no currently reliable statistical information which would fully reflect their volumes. First, this is closely connected to the absence of clear legislative regulation in Ukraine of each type of CR, which complicates control over their implementations; Secondly, companies that cooperate with foreign customers in the $\mathrm{CR}$ format are not required to report to them and disclose full information about their counterparties, order volumes and sphere of its application and use. Also, in the face of fierce competition, businesses are reluctant to disclose information that may affect the success of their running, and lead to the loss of the client (customer or consumer).

According to our expert estimationsas for the extent of contractual relations in Ukraine to which foreign element is involved, they should not be limited only by the volume of export/import of tolling raw materials, processing services or the cost of outsourcing contracts. It should also include the volumes of related service and related industries, the volume of processed licenses and sales derived from them, the natural and monetary volume of the agricultural and industrial sector production (if contract farming is taken into account), and, importantly, the number of job positions created during the implementation process of contractual relations between non-residents.

Measuring and recording of volumes of contractual relationships is an important step in understanding the scale and trends of further development of production and marketing, trade and investment. We share the multi-level approach of UNCTAD experts [14] for evaluation of the scope and volume of the global contracting phenomenon. This approach reflecting the complexity of CR's and their interconnection with other trading and investing transactions is as follows.

First, the prevalence of some types of CR's (by type of cooperation) should be differentiated between industries, i. e. the number of volumes of CR's used in a particular industry should be taken into account. For example, manufacturing contract is the most spread in the field of electronics, production of apparel and footwear, spare auto parts, and other industries. Most often, UNCTAD experts offer information on the industry-type combination in two ways:

- in case where it is possible according to industry analysis data, industry associations or advisory agencies. It is suggested to clarify the information obtained by analyzing the biggestmembersof each market and adjusting total sales of CR's (means, 
the volume of products export generated by the contractual relations between residents of different countries) by an appropriate coefficient of internationalization to obtain a refined cross-border trade volume $\mathrm{CR}$;

- in case where there is no information on CR volumes, it is proposed to assess cross-border CR trade by subtracting re-exports from world exports volumes of those goods that characterize trading of specific type of CR (e. g. clothing, shoes, toys traded by contract msnufacturing). The number obtained should be multiplied by the percentage (calculated on the basis of industry reports and interviews) of the export of the CR type combination in order to obtain the result as close as possible to reality.

Second, in most cases, the value added attributable to cross-border sales of CR's is estimated by applying a value ratio (calculated as sums of income before tax, personnel and depreciation expenses) to export volumes of representative companies' samplein each industry. For franchisingit is best to obtain statistical information from franchise organizations.

Third, it is proposed to measure «the number of job positions created» by typeindustry combinations both overall and separate in developing countries and in transitional economies:

- in case of the combination type-industry, the market is highly concentrated (contract manufacturing in electronics, auto parts, and pharmaceuticals; contract management in the hotel sphere), so the assessment of cross-border employment is carried out as follows: total number of job positions created by companies in a certain industry taken, which is multiplied by their market share in the global CR market in their industry and by the percentage of internationalization. Assessment of employment rates in transitive and developing countries are based on the share of assets or employment of the largest companies in the total «number of job positions created»;

- in case where the concentration on the market is low (contract manufacturingin the light industry), the overall employment rate is estimated using the UNIDO industry index to determine the worldwide employment rate of in a particular field, to which a specific industry coefficient calculated as a proportion of manufacture applied export products, which is used to calculate the export share of given industrytype combination. The estimation of the employment rate in transitive economies and developing countries is done by subtracting the share of the total employment rate due to $\mathrm{CR}$ worldwide.

We propose to implement this methodology to assess the scales of contractual relations in Ukraine at the first level, i. e. to determine the volume of export/import of contractual relations. In Table 1 the estimated volumes of the dynamics of contractual relations by type in Ukraine areshown. The data in Table 1 is divided into two vectors: export is the volume of non-resident orders; import is those services provided by a foreign entity to Ukrainian counterpart.

In the whole, from the point of view of research correctness, it is really difficult to track the steady tendency in the development of contractual relations on the Ukrainian territory: from year to year, both inbound and outbound flows show quick 
reduction, or tremendous increase. According topredictionsof CR use in Ukraine is more challenging. Therefore, to forecast the prospects of Ukraine's participation in international contractual relations, we use the method of extrapolation of trends in CR by species based on previously obtained data for 2010-2016, although we admit the limitations of this approach. The use of the extrapolation method is justified by the lack of knowledge about the nature of the phenomenon being studied, or the lack of data needed to apply more advanced forecasting methods, and in the case of contractual relations in Ukraine it goes right about it. In accordance with the proposed approach, we projected exports and imports of contractual services in Ukraine for 2020, 2025 and 2030 (Table 1).

Table 1

\section{Real and predictive indicators of the use of international contractual relations in Ukraine}

\begin{tabular}{|c|c|c|c|c|c|c|c|c|}
\hline \multirow{2}{*}{ Years } & $\mathrm{L}$ & $\mathrm{O}$ & $\mathrm{CM}$ & $\mathrm{CP}$ & $\mathrm{L}$ & $\mathrm{O}$ & $\mathrm{CM}$ & $\mathrm{CP}$ \\
\cline { 2 - 9 } & \multicolumn{7}{|c|}{ Export, US million dollars } & \multicolumn{3}{c|}{ Import, US million dollars } \\
\hline 2010 & 132,00 & 404,00 & 530,00 & 1326,00 & 744,00 & 210,00 & 618,00 & 5,00 \\
\hline 2011 & 107,00 & 658,00 & 642,00 & 1805,00 & 746,00 & 255,00 & 629,00 & 8,00 \\
\hline 2012 & 124,00 & 937,00 & 753,00 & 2077,00 & 727,00 & 334,00 & 618,00 & 10,00 \\
\hline 2013 & 167,00 & 1292,00 & 892,00 & 1951,00 & 1072,00 & 398,00 & 632,00 & 11,00 \\
\hline 2014 & 118,00 & 1500,00 & 727,00 & 1278,00 & 552,00 & 337,00 & 453,00 & 29,00 \\
\hline 2015 & 85,00 & 1668,00 & 508,00 & 1078,00 & 358,00 & 327,00 & 375,00 & 63,00 \\
\hline 2016 & 73,00 & 1975,00 & 501,00 & 1118,00 & 358,00 & 323,00 & 400,00 & 5,00 \\
\hline \multicolumn{8}{|c|}{ Predictive indications } \\
\hline $\mathbf{2 0 2 0}$ & 112,91 & 8010,93 & 917,12 & 1177,25 & 337,51 & 481,08 & 474,55 & 5,42 \\
\hline $\mathbf{2 0 2 5}$ & 194,77 & 46113,40 & 1952,80 & 1255,74 & 313,53 & 791,55 & 587,58 & 6,00 \\
\hline $\mathbf{2 0 3 0}$ & 335,96 & 265443,19 & 4158,07 & 1339,46 & 291,26 & 1302,38 & 727,53 & 6,64 \\
\hline
\end{tabular}

Source: calculated by the authors on the basis of10; 11; 12; 13.

Table symbols: L - licensing, $\mathrm{O}$ - outsourcing, CM - contract management, $\mathrm{CP}$ - contract production

The following perspective trends of CR development in Ukraine have been identified: outsourcing and contract management are experiencing significant growth in export positions, licensing grows at a moderate pace, for example, it is projected that in 2020 its volumes will reach the level of 2012, contract production is not to increase significantly and in 2030 it will reach the level of 1339.38 million US dollars, which is close to the value marked in 2010. Imports are predicting significant decline in licensing by 2030, while other types of CRshow a slight increase over the period of 2020 to 2030.

Taking into account the fact that the types of CR are significantly different from each other in terms of their implementation, the effects they create, and by the consequences (both negative and positive) that they generate, it is advisable to 
consider possible directions of their most effective application in Ukraine, based on the determinants for their location in combination with the necessary conditions for development of each type. To do this, we are encouraged to implement balanced policies in the following directions:

- optimization of the financial and economic vector: measures to alleviate the tax burden for enterprises in order to free up funds for expanding and updating the production base, innovative development, improving the quality of processes and products;

- ensuring the development of small and mediumbusinesses, which is the basis for the development of the national economy being the most relevant (up to date)issue in the way of simplifying and cheapening access to financial resources;

- remediation and stimulation of technological and innovation clusters development in parallel with the investment attraction policy;

- creation of innovative infrastructure, cooperation of research scientific establishments with business and state, development of venture business, integration of enterprises into technological and innovative alliances to consolidate their resources;

- - creation of conditions for active absorption and development of knowledge, skills, abilities, technologies, standards, business models, etc., which is a component of cooperative relations;

- systematization of legislative and regulatory acts relating to both aspects of international cooperation and other contractual relations;

- adjusting the mastering of international cooperation and contractual relations in accordance with the priority directions of the country's development;

- development of such important elements for contractual relations of the organization of economic activity such as transport, warehousing and communication infrastructure, etc.

Conclusion. The analysis of the determinants and prospects of the development of international contract relations in Ukraine allows us to formulate certain conclusions and generalizations:

- contract relations in the format of international production and marketing cooperation should be considered as a component of combined model for national economic development, both external and internal sources and resources of extended reproduction in the context of intensifying of non-protectionist tendencies in the leading countries of the world and through intensifying national development risks;

- the analysis of the sectoral specifics of the development of contractual relations revealed their weak diversification in global trends and the priority of a limited circle of contracts, namely contractmanufacturing in the sphere of raw materials processing;

- limitations for further development of contractual relations are caused by weak institutional support, in particular lack of legislative support, adequate logistical and organizational infrastructure; 
- serious complication in predicting volumes and structure of operations mediated by international contractual relations is the imperfection of the national accounting system and poor motivation of the business, which is integrated into the international cooperative activity to promulgation of the operations outlined;

- contract management and manufacturing, outsourcing, licensing has been identified as promising sector and activity in the context of international contract relations with the participation of domestic business entities.

\section{REFERENCES}

1. Duhinets, H.V. (2016). Liudskyi kapital v umovakh rozvytku hlobalnykh lantsiuhiv stvorennia vartosti [Human capital in the context of the development of global value chains]. Zbirnyk naukovykh prats Cherkaskoho derzhavnoho tekhnolohichnoho universytetu - Collection of scientific works of Cherkasy State Technological University, 41(2), 24-30. Retrieved from http://nbuv.gov.ua/UJRN/ Znpchdtu_2016_41(2)_6[in Ukrainian].

2. Mazaraki A., Melnichenko S., Duginets G., et al. Ukrainian economy growth imperatives: Monograph. Prague: Coretex CZ SE, 2018.

3. Melnyk, T. \& Kudyrko, L. (2018). Features of Ukraine participation in international contractual relations. Baltic Journal of Economic Studies, 1, 276-282.

4. Miroudo S., Lanz R., Ragoussis A. (2009). OECD Trade Policy Working Paper: Trade in intermediate goods and services. Retrieved from: http://www.oecd.org/dataoecd/47/14/44437205.pdf.

5. Postanova Kabinetu Ministriv Ukrainy pro skhvalennia «Prohnozu ekonomichnoho i sotsialnoho rozvytku Ukrainy na 2018-2020 roky» № 411vid 31.05.2017 [Resolution of the Cabinet of Ministers of Ukraine on approval of the Forecast of economic and social development of Ukraine for 2018-2020]. zakon.rada.gov.ua. Retrieved fromhttps://zakon.rada.gov.ua/laws/show/411-2017$\% \mathrm{D} 0 \% \mathrm{BF}$ [in Ukrainian].

6. Proekt Zakonu Ukrainy «Pro Derzhavnyi biudzhet Ukrainy na 2018 rik» № 2246-VIII vid 07.12. 2017 [Draft Law of Ukraine «On the State Budget of Ukraine for 2018»]. zakon.rada.gov.ua. Retrieved from http://w1.c1.rada.gov.ua/pls/zweb2/ webproc4_1?pf3511=62551 [in Ukrainian]

7. Reznikova, N.V. \& Ivashchenko, O. (2015). Perspektyvy uchasti Ukrainy v hlobalnykh lantsiuhakh stvorennia vartosti yak zasib pidvyshchennia konkurentospromozhnosti v umovakh transnatsionalizatsii vyrobnychykh vidnosyn [Prospects for Ukraine's participation in global value chains as a means of increasing competitiveness in the context of transnationalization of industrial relations]. Investytsii: praktyka ta dosvid - Investment: practice and experience, p. 22-26 [in Ukrainian].

8. Reznikova, N.V. (2018). Kontraktni vidnosyny $\mathrm{v}$ stratehiiakh intehratsii krain $\mathrm{v}$ hlobalni lantsiuhy stvorennia vartosti [Contractual relations in strategies of 
countries integration into global value chains]. Ekonomichnyi prostir - Economic space, p. 137 [in Ukrainian].

9. Rohach, O. (2013). Kharakterni rysy rozvytku mizhnarodnoho vyrobnytstva TNK $\mathrm{v}$ postkryzovyi period [Characteristic features of the development of international production of TNCs in the post-crisis period]. Aktualni problemy mizhnarodnykh vidnosyn - Actual problems of international relations, 112, 276-280 [in Ukrainian].

10. Statystychna informatsiia «Tovarna struktura zovnishnoi torhivli Ukrainy» [Statistics on Commodity structure of Ukraine's foreign trade]. Derzhavna Sluzhba Statystyky Ukrainy - State Statistics Service of Ukraine, 2004-2016. Retrieved from https://ukrstat.org/ [in Ukrainian].

11. Statystychna informatsiia «Zovnishnia torhivlia Ukrainy tovaramy ta posluhamy» [Statistics on Ukraine's Foreign Trade in Goods and Services]. Derzhavna Sluzhba Statystyky Ukrainy - State Statistics Service of Ukraine, 20122016. Retrieved from https://ukrstat.org/ [in Ukrainian].

12. Statystychna informatsiia «Zovnishnia torhivlia Ukrainy tovaramy ta posluhamy» [Statistics on Ukraine's Foreign Trade in Goods and Services]. Derzhavna Sluzhba Statystyky Ukrainy - State Statistics Service of Ukraine, 2017. Retrieved from https://ukrstat.org/ [in Ukrainian].

13. Statystychna informatsiia «Zovnishnia torhivlia Ukrainy» [Statistics on Ukraine's Foreign Trade]. Derzhavna Sluzhba Statystyky Ukrainy - State Statistics Service of Ukraine, 2009-2017. Retrieved from https://ukrstat.org/ [in Ukrainian].

14. United Nations conference on trade and development. World Investment Report 2011: Non-Equity Modes of International Production and Development. United nations publication, 2011, $251 \mathrm{p}$.

15. Zvarych I. International Production Chains in Europe: Position of Ukraine / Local Production Systems: Analysis and Forecasting of Regional Economic Development led. by A.S. Novoselov and V.E. Seliverstov. Novosibirsk, Sofia, Lodz, Banska Bystrica, Ternopil, 2015, 362 p.

16. Zvarych, I. (2018). Spetsializatsiia na vyrobnytstvi promizhnykh tovariv yak peredumova rozvytku ta pohlyblennia mizhnarodnykh kooperatsiinykh vidnosyn [Specialization in the production of intermediate goods as a prerequisite for the development and deepening of international cooperative relations]. Ekonomichnyi prostir-Economic space,p. 138 [in Ukrainian]. 